\title{
THE COMMISSION OF INQUIRY IN THE PERSPECTIVE OF ADMINISTRATIVE LAW
}

\begin{abstract}
R. A. MACDONALD*
In an analysis of the role of public commissions of inquiry, the author discusses the various forms, classifications and rationales usually given for such inquiries, and examines judicial review proceedings in particular cases and current administrative law doctrine in light of the theory behind the creation of commissions. A new theory of judicial review is then offered based upon a number of functions which an ad hoc commission might serve.
\end{abstract}

\section{INTRODUCTION}

Royal Commissions, Commissions of Inquiry, Public Inquiries, Committees of Investigation, Departmental Investigations and Advisory Commissions are assuming an ever increasing significance in the Canadian governmental process. Each is a particular example of an institution which performs what traditionally has been known to administrative lawyers as the "investigatory and/or recommendatory function". ${ }^{1}$ But unlike investigative and recommendatory processes which occur within the context of a well-defined, highly developed and continuing administrative structure (e.g., tax investigations under the Income Tax Act, coroners' inquests under the Criminal Code, special inquiries under the Immigration Act), the ad hoc Commission of Inquiry has a specialized role in the Canadian legal system. ${ }^{2}$ Habitually these inquiries are asked to look into matters of public importance which are of an extraordinary nature. Often they are the object of substantial external criticism-in their mandate, their personnel, their procedures and their recommendations. Sometimes the failure to appoint a commission in a certain instance generates as much controversy as the actual appointment of others. Always, however, they are a highly visible government instrumentality. For these reasons alone it would be instructive to examine the political, constitutional and legal role of the inquiry in Canada and the rationale for its creation as an institution of government. But such an examination is even more timely today in view of several events of relatively recent vintage: the proposal by the Law Reform Commission of Canada for the enactment of a new federal Inquiries Act, ${ }^{3}$ and the attacks by way of judicial review on the constitutionality, ${ }^{4}$ member-

* Associate Professor, Faculty of Law, McGill University. The author would like to thank Stuart McCormack, a former student at the Faculty of Law, University of Windsor, for his assistance in the development of the theses set out in this paper.

1. For a general discussion, see Howe, "The Applicability of the Rules of Natural Justice to Investigatory and Recommendatory Functions" (1974) 10 O.H.L.J. 179 esp. 184-190; Wade, Administrative Law (4th ed. 1978) ch. 24.

2. The observations of Reid, Administrative Law and Practice (2nd ed. 1978) 93, on judicial review cases dealing with inquiries are instructive: "Decisions on public inquiries must always be considered rather special in administrative law and may be of little general value". For a recent example of judicial review of a bureaucratic inquiry see Re Evans and Milton et al. (1979) 24 O.R. (2d) 181, which concerned a coroner's inquest.

3. Law Reform Commission of Canada, Working Paper 17, Administrative Law: Commissions of Inquiry (1977). See most recently, Report 13. Advisory and Investigatory Commissions (1979), which incorporates without major modification the proposals of the Working Paper.

4. Di Iorio and Fontaine v. Warden of the Common Jail of Montreal and Brunet et al. (1977) 73 D.L.R. (3d) 491; A.G. Quebec and Keable v. A.G. Canada et al. (1978) 90 D.L.R. (3d) 161. 
ship, ${ }^{5}$ procedures, ${ }^{6}$ and recommendations ${ }^{7}$ of several inquiries appointed during the past decade. ${ }^{8}$

Commissions of inquiry have been discussed in a substantial body of literature over the past thirty years. ${ }^{9}$ In specialized studies of individual commissions and general reviews of the phenomenon as an aspect of our system of government, political scientists and public administrators have devoted considerable energy to detailing how inquiries function. By way of contrast, until recently little work has been devoted to examining the justification for commissions of inquiry from the strictly legal point of view-that is, to tracing the procedural and judicial review implications of their juridical characterization. ${ }^{10}$ Such a task will be the primary focus of this study. Part II will consist of an investigation of the various forms, classifications and rationales usually given for inquiries, and will include an analysis of the recommendations of the Law Reform Commission of Canada. In Part III closer attention will be paid to problems arising from specific commissions of inquiry; judicial review proceedings in particular instances will be examined in order to determine if current administrative law doctrine is congruent with the theory offered by political scientists and public administrators for creating the commission of inquiry. Finally, in Part IV some conclusions as to the legal purposes of inquiries and the implications of these purposes will be drawn; an alternative legal model

5. Re Copeland and McDonald et al. (1978) 88 D.L.R. (3d) 724.

6. Re $B$ and Commission of Inquiry Re Department of Manpower and Immigration (1976) 60 D.L.R. (3d) 339; Landreville v. The Queen (No. 2) (1977) 75 D.L.R. (3d) 380.

7. Cotroni v. Quebec Police Commission (1977) 80 D.L.R. (3d) 490.

8. See also the following cases involving judicial review of inquiries: Reference re a Comm'n of Inquiry into the Police Dep't of Charlottetown (1977) 74 D.L.R. (3d) 422; Re Royal Comm'n of Inquiry into the Activities of Royal American Shows Inc. (No. 2) (1977) 39 C.C.C. (2d) 28; Re Anderson and Royal Comm'n into Activities of Royal American Shows Inc. (1978) 82 D.L.R. (3d) 706; Royal American Shows Inc. v. Laycraft (1978) 82 D.L.R. (3d) 161; Re Royal Comm'n into Metropolitan Toronto Police Practices and Ashton (1975) 64 D.L.R. (3d) 477; Re Inquiry into the Confidentiality of Health Records in Ontario (1978) 90 D.L.R. (3d) 576; Re Bortolotti and Ministry of Housing (1977) 76 D.L.R. (3d) 415; Re Royal Comm'n on Conduct of Waste Management Inc. (1977) 17 O.R. (3d) 207.

9. The more important monographs are: Salmon, Tribunals of Inquiry (1967); Cartwright, Royal Commissions and Departmental Committees in Britain (1975); Rhodes, Committees of Inquiry (1975); Chapman, The Role of Commissions in Policy Making (1973); Wraith and Lamb, Public Inquiries as an Instrument of Government (1971); Hamilton, The Power to Probe (1976); Hanser, Guide to Decision: The Royal Commission (1965); Clokie, Royal Commissions of Inquiries (1937). Periodical literature is somewhat less comprehensive. Canadian articles include: "The Mackenzie Valley Pipeline Inquiry" (1976) 3 Queen's L.J. 3; LeDain, "The Role of the Public Inquiry in Our Constitutional System" in Ziegel (ed.) Law and Social Change (1973); Sellar, "A Century of Commissions of Inquiry" (1947) 25 Can. Bar Rev. 1; Courtney, "In Defence of Royal Commissions" (1969) 12 Can. Pub. Admin. 198; "Symposium: To Commission or not to Commission" (1962) 5 Can. Pub. Admin. 253; Lockwood, "A History of Royal Commissions" (1967) 5 O.H.L.J. 172; Hanson, "Inside Royal Commissions" (1969) 12 Can. Pub. Admin. 356; Walls, "Royal Commissions: their influence on public policy" (1969) 12 Can. Pub. Admin. 365; Doern, "The Role of Royal Commissions in the general policy process and in federal-provincial relations" (1967) 10 Can. Pub. Admin. 417; Hodgetts, "Should Canada be De-Commissioned?" (1964) 70 Queen's Quarterly 479.

10. Among studies which do not offer such analysis are Working Paper 17 and Report 13 of the Law Reform Commission of Canada, and Section 4 of Part I of the McRuer Royal Commission Inquiry into Civil Rights (1968) at 383-496. Legal periodical literature includes: "Rapport du Comité d'étude du Québec sur les commissions d'enquête" (1976) $R$. du B. 545; Crête, "L'enquéte publique et les critères de controle judiciaire des fonctions exercées par les enquêteurs" (1978) 19 C. de D. 643; Crete, "L'enquête publique et le pouvoir de condamnation pour outrage au tribunal" (1978) $19 C$. de D. 859; Molot, "Administrative Discretion and Current Judicial Activism" (1979) 11 O.H.L.R. 337 at 345-352; Henderson, "Abuse of Powers by Royal Commissions" [1979] Special Lectures of L.S.U.C. 493. Yet, even these studies are rather traditional in their orientation; while usually recommending tighter supervision of inquiries and a diminution of their powers, they do not offer a theoretical framework of justification for such proposals. 
of ad hoc commissions, and concomitantly, a new theory of judicial review of inquiries then will be sketched.

As a preliminary to this study, however, it is appropriate to clarify some of the terminological confusion which permeates discussions of inquiries, for often expressions such as Public Inquiry, Royal Commission and Committee of Investigation are used interchangeably.10a Strictly speaking, a Royal Commission is a commission issued to an individual under the Great Seal of Canada (or the Great Seal of a Province) pursuant to the exercise of prerogative power.11 Most often such Royal Commissions are expressly made subject to the provisions of the relevant federal or provincial Inquiries Act but there is no necessary reason for this to be the case. In fact, where there is no reference to such Acts, the powers and procedures of the Commission are those as set out in its Letters Patent under the Great Seal. ${ }^{12}$

On the other hand, an ordinary Public Inquiry (which is often mistakenly referred to as a Royal Commission) is established by order-incouncil pursuant to an Inquiries Act or to any other statute which gives the Governor-in-Council (or Lieutenant-Governor-in-Council) such power..$^{13}$ Normally, the powers and procedures of a Public Inquiry will be identified in the order-in-council by which it is created, in an Inquiries Act, or in the generic statute under which the order is issued. For example, specialized but ad hoc inquiries pursuant to ordinary statutes often will be made subject to the provisions of an Inquiries Act with respect to their powers and procedures. ${ }^{14}$ Public Inquiries will sometimes be granted powers by reference to the procedures of a court 15 and sometimes with no procedural referent whatsoever, ${ }^{16}$ in which case reference must be had to the constitutive order-in-council.

A third ad hoc governmental inquiry device is the Committee of Investigation or the Departmental Investigation. At the federal level such investigations are established by the appropriate Minister under authority delegated by the Governor-in-Council, and are usually subject to the provisions of Part II of the Inquiries Act.17 However, other departmental investigations may operate on a purely informal basis.17a Provincially, no distinction is drawn between inquiries and investigations in most jurisdictions, and apart from informal departmental investigations, all Committees of Investigation are appointed under Inquiries Acts or other generic legislation. ${ }^{18}$

Hence, from a legal point of view, it is apparent that these various terms reflect important differences in the source of an ad hoc inquiry's

10a. Henderson, supra n. 10, provides a useful historical introduction to inquiries. See pp. 494-498. See also the statement by the McDonald Commission reported at (1978) 44 C.C.C. (2d) 200, especially at 205-207.

11. L.R.C. Working Paper 17 at 5.

12. Lockwood, supra n. 9 at 174-176. See Kelly v. Mather (1915) 23 D.L.R. 225 for an outline of constitutional limitations on the powers of Royal Commissions at common law.

13. See McRuer, supra n. 10 at $463-465$.

14. L.R.C. Working Paper 17 at 10, 77-81; McRuer, supra n. 10 at 463, 466-477. These are not to be confused with ordinary investigatory or recommendatory functions created by statute.

15. McRuer, supra n. 10 at $463,477-481$. Such a grant of power may, however, only be given by statute.

16. L.R.C. Working Paper 17 at 10, 83-86.

17. Id. at 7-11.

17a. For example, it is always within the power of a Minister qua Minister to order an informal investigation of, or within his department.

18. McRuer, supra n. 10 at 385-387. 
jurisdiction: Royal Commissions are established through the exercise of the Crown Prerogative; Public Inquiries are creatures of legislation or, exceptionally, delegated legislation; Investigations tend to result from the informal exercise of a Minister's power to manage his department, although federally they may in certain cases derive their power from statutory authority under the Inquiries Act. Despite these differences (which may marginally affect the reviewability of an Inquiry on some grounds), ${ }^{19}$ all the above-mentioned ad hoc institutions perform, to a large degree, the same investigatory and recommendatory function (a function which, moreover, in many respects parallels that of inquiries established for the purpose of carrying out the scheme of a statute). ${ }^{20}$ To avoid confusion, in this paper "commission of inquiry", "inquiry" and "commission" will be used interchangeably as general descriptive terms referring to ad hoc institutions; "investigatory" will be used in a functional sense, usually in contrast to "advisory" or "recommendatory"; the labels "Royal Commission" and "Public Inquiry" will be employed only in their technical senses.

\section{THE NATURE, RATIONALE, FORMS AND CLASSIFICATION OF INQUIRIES}

It has often been noted that inquiries do not fall squarely within any one of the traditional branches of government-legislative, executive, judicial. $^{21}$ Much like the administrative agency, especially when it appears in its independent or semi-independent variant, ${ }^{22}$ the ad hoc inquiry has close links with the executive but is legally distinct from the public bureaucracy. In essence, the inquiry is a sui generis government instrumentality, which possesses the following basic characteristics: its processes are public, its creation is ad hoc, and its legal objective is an investigatory/advisory report rather than a definitive decision. ${ }^{23}$ From these characteristics T. J. Cartwright derives three conclusions which he feels are descriptive of inquiries. He notes: ${ }^{24}$

1. that royal commissions and departmental committees constitute a unique but ubiquitous institution of government;

2. that, as such, they demonstrate a quite remarkable degree of flexibility and adaptiveness;

3. that they provide a unique kind of mechanism for public participation in government.

The Law Reform Commission of Canada offers support for the first of these propositions with its observation: "Much of the history of Canada could be interpreted through the work of commissions of inquiry". ${ }^{25}$ The

19. See Molot, supra n. 10 at 352; Henderson, supra n. 10 at 494-498.

20. The organization and recommendations of the McRuer Report reflect this perception (at 385400; 463-465) as does that of L.R.C. Working Paper 17 (at 5-11; 23-26). See infra Part IV for a discussion of salient differences between ad hoc and regular inquiries.

21. Cartwright, supra n. 9; L.R.C. Working Paper 17; Wheare, supra n. 9; Rhodes, supra n. 9; Henderson, supra n. 10 at 498.501 . An attempt by a Commission to itself comment on the nature of an Inquiry may be found in (1978) 44 C.C.C. (2d) 200 at 205-207.

22. See, for an evaluation of the legal status of such tribunals, Janisch, "The Role of the Independent Regulatory Agency" (1978) 27 U.N.B.L.J. 81; "Policy-Making in Regulation: Towards a New Definition of the Status of Independent Agencies in Canada" (1979) 17 O.H.L.J. 46.

23. These characteristics are developed carefully by Doern, supra n. 9 at 417-419.

24. Cartwright, supra n. 9 at $3-4$.

25. L.R.C. Working Paper 17 at 11. 
Commission reports that from 1867 through 1977 over 400 commissions of inquiry were appointed under Part I of the federal Inquiries Act (or its predecessors); and during the past century almost 1,500 Departmental Investigations were appointed under Part II of the same statute. ${ }^{26}$ But these statistics do not tell the complete story. For, as the Law Reform Commission has observed, it is often unclear whether an inquiry actually exists: 27

It is difficult if not impossible to discover the exact number of inquiries that have been constituted under the various versions of the Inquiries Act. . . Sometimes it is uncertain under what authority a commission of inquiry has been appointed. On some occasions, a royal warrant was issued, but no order-in-council can be discovered; some commissions appear to have been established without either a royal warrant or an order-in-council.

If these figures and observations are reasonably extrapolated over all provincial governments as well, it is clear that ad hoc inquiries are a major governmental institution. ${ }^{28}$

Cartwright's second observation, that inquiries exhibit a remarkable degree of flexibility and adaptiveness, merits greater attention. ${ }^{29}$ From the fact that inquiries are invariably appointed ad hoc to deal with some matter of public concern, it follows that they do not adhere to one unalterable bureaucratic form of organization, nor do they function in a bureaucratic fashion. It is to this feature that their adaptiveness is principally attributable. In one sense, bureaucracies can be seen as a structure organized so as to present a predetermined set of responses to a finite number of preconceived problems; they are designed and staffed to respond best to these anticipated situations. But such an organizational structure works only if the challenges faced by a bureaucracy actually reflect the problems it was designed to handle; if new or unforeseen problems arise, the static hierarchical structure of bureaucracies compels these to be forced into the pre-existing response mould. Hence, a major problem in government is finding the appropriate process or institution to respond to a challenge which cannot be handled effectively by existing bureaucratic structures. From an internal perspective (i.e. that of public administration) the commission of inquiry is ideally suited for managing these cases: its personnel, powers, procedures, mandate and goals may be tailored ad hoc to deal with almost any situation.

The Law Reform Commission has made this point in another way. Early in its Working Paper it notes that inquiries "supplement the mainstream institutions of government by performing tasks that these institutions are likely to do less well". ${ }^{30}$ Inquiries are seen as bringing an objectivity, impartiality and expertise to problem solving which neither

26. Id. at 10 .

27. Id.

28. The Law Reform Commission observes that at least 47 federal statutes confer powers of inquiry on various individuals and refer expressly to the Inquiries Act as the procedural guide for such inquiries. See id. at 10,77.81. For Ontario statistics see McRuer, supra n. 10 at 463, 466-477. Moreover, at least forty other federal statutes confer a variety of powers of inquiry without making reference to the Inquiries Act. See id. at 10, 83.86. To the extent that these other inquiries are ad hoc and are established outside the regular framework of an administrative process, they too are contemplated in the current discussion of inquiries. On the other hand, if they are merely investigatory and/or recommendatory functions which are a regular part of a statutory scheme, they are not meant to be included in the discussion which follows.

29. Much of this paragraph is, in fact, adapted from Cartwright.

30. L.R.C. Working Paper 17 at 17. 
the executive nor legislative branches can be expected to possess. Politicians and public servants are unlikely to be intimately involved with the subject matter of the inquiry; nor do they possess the expertise and freedom necessary to resolve the often complex, interdisciplinary problems relegated to inquiries. Moreover, because inquiries are not tied to the constraints of a legislative or executive timetable, they are able to devote sufficient time to mulling over difficult points. Again, inquiries are able to adopt procedures and methodologies for accomplishing their mandate which would be inappropriate, were such tasks delegated to the judiciary: adjudication presupposes a pre-existing law to be applied and the presentation of facts which have been unearthed by others; the judicial process also presumes the existence of an issue which is formulated in advance and which can be answered with a yes/no response.30a Finally, although the police and other public servants such as coroners are familiar with certain investigatory aspects of inquiries, their expertise lies in very specialized areas and does not touch topics as diverse as maladministration, failure to implement policy, corruption or organizational difficulties. In summary, from the external, or political perspective, a major rationale for the commission of inquiry is connected to the fact of its flexibility and adaptiveness. The ad hoc inquiry performs an important supplemental role to the executive, legislative and judicial branches of government precisely because, unlike the latter, it is not a bureaucratic institution. ${ }^{31}$

The third significant feature of inquiries highlighted by Cartwright is their ability to act as a major vehicle for public participation in government. This point has two distinct aspects: first, participation by the public is institutionally guaranteed, and secondly, this participation is in public. ${ }^{32}$ With respect to many inquiries the solicitation of input from the general public forms an important goal of the process: information as to public opinion and education of public opinion are both desired in their own right. ${ }^{33}$ In other inquiries, the public nature of the process is a means to achieving other goals: these may be as diverse as the voicing of grievances, the forestalling of criticism and the "rendering acceptable" of conclusions proposed by the inquiry. ${ }^{34}$ Some authors ${ }^{35}$ note that many of the justifications advanced in support of inquiries indirectly relate to their two-fold public nature. LeDain is more explicit: ${ }^{36}$

I believe it is a legitimate object to use it [the inquiry] for the purpose of developing public awareness and understanding of a complex problem and allowing time for the development and identification of public attitudes. . . . I think that a public inquiry can respond to the need for some extension of the regular electoral process on the social level, a process in which the public can contribute to the identification and discussion of the issues.

30a. Paradoxically, many writers recommend increased judicialization of inquiries. See Henderson, supra n. 10 at $497-498,530$.

31. While the characterization of the judiciary as a bureaucracy may strike the lawyer as forced, support may be found in almost all works on public administration. See, e.g., Pfiffner and Presthus, Public Administration (5th ed. 1967) ch. 3, and compare Schubert, Judicial Policy Making (1965).

32. Cartwright, supra n. 9 at 6.

33. L.R.C. Working Paper 17 at 15, 19, 20-21.

34. Willis, "Comment on the Role of the Public Inquiry . . ." in Ziegel (ed.) Law and Social Change (1973) at 99 .

35. "Symposium: To Commission or Not to Commission", supra n. 9; Wheare and Lamb, supra n. 9 at 309-313.

36. LeDain, supra n. 9 at 81,84 . 
This perspective is also shared by the Law Reform Commission. $36 \mathrm{a}$

Given these underlying and important features, to what political and administrative uses can the inquiry legitimately be put? Most commentators, including, by implication, the Law Reform Commission of Canada, seem to be in accord with Hodgetts, who suggests six principal functions of commissions of inquiry: ${ }^{37}$ (a) they enable the government to secure information as a basis for developing or implementing policy; (b) they serve to educate the public or the legislative branch; (c) they provide a means to sample public opinion; (d) they can be used to investigate the judicial or administrative (police, civil service, Crown corporations) branches; (e) they permit the public voicing of grievances; $(f)$ they enable final action to be postponed. In other words, politically the inquiry should be viewed as a multi-purpose instrument which can serve as an effective governmental device for co-opting the public into the investigatory and advisory processes of the state. Rather than a regular institution of the public bureaucracy charged with achieving specified goals, the ad hoc inquiry is a creature whose ultimate goals are not specified in other than procedural terms. Not a principal mechanism for effectuating government policy, the inquiry nevertheless facilitates the development, the implementation and the final acceptance of particular state initiatives in those areas it has examined. In each of the above ways, the commission also performs a variety of important functions in the realm of public administration. ${ }^{38}$

It is, however, a large jump from the identification of the salient political and administrative characteristics of inquiries to the derivation of concrete legal implications of these characteristics in terms of the powers and procedures of commissions. An important intermediate step involves the question of whether a legal taxonomy of inquiries may be developed; for the law (and lawyers) habitually deals with problems by drawing distinctions and isolating important similarities. Specifically, one must consider whether the commission of inquiry is a legal monolith, or whether a functional catalogue of its differing variants can be articulated. Some authors have proposed a variety of tests for distinguishing the main species of commissions of inquiry; formal features such as status (ad hoc or standing), nomenclature (inquiry, investigation, commission, committee, etc.), terms of reference and powers, membership, and procedure are the most usual among these. ${ }^{39}$ Yet it is obvious that none of the above relate fundamentally to the legal nature of the inquiry process. Status and nomenclature may be the result of political accident; powers, membership and procedure are infinitely variable. A taxonomy which would be of use to lawyers in understanding the powers and

36a. L.R.C. Working Paper 17 at 15-21.

37. Supra n. 9 at 480 . Clokie, in a study more concerned with advisory/recommendatory inquiries (supra n. 9), offers a similar catalogue. He states that commissions may be used to: (i) prepare the way for a predetermined government policy; (ii) ascertain in a more or less "expert" fashion the best or most feasible solution of a problem the government desires to tackle but on which it has made no final decision; (iii) delegate to a representative body the task of solving some major economic or social controversy which the cabinet does not feel called upon to settle; (iv) forestall public criticism or prevent anticipated political pressure; (v) postpone as long as possible the consideration of a question distasteful to the government and at the same time to pacify some politically powerful section of the public.

38. The role of the inquiry in the process of public administration is emphasized in Wraith and Lamb, supra n. 9.

39. See the discussion in Rhodes, supra n. 9 at 27. 
procedures of inquiries, if any may be developed, must therefore be based not on purely formal criteria, but on functional standards.

The traditional approach to classification on this basis is to bifurcate inquiries into those which are advisory (recommendatory) and those which are investigative.40 Under such a characterization, advisory inquiries are said to be those structured to recommend legislative policy: "They address themselves to a broad issue of policy and gather information relevant to that issue". ${ }^{41}$ Investigatory inquiries, on the other hand, are held to be those established to investigate conduct: "They address themselves primarily to the facts of the particular alleged problem, generally a problem associated with the functioning of government". ${ }^{2}$ LeDain notes that, although this distinction has a certain degree of validity, it is extremely difficult to draw in practice, as many inquiries both recommend and investigate. ${ }^{43}$ For example, recommendation and advice on policy options involves factual investigation and the revelation of specific problems arising from prior policy (or lack of it), while investigation of conduct will usually result in the recommendation of policy changes to avoid like occurrences in the future. Nevertheless the majority of authors feel that inquiries primarily either advise or investigate and that this distinction should be legally significant.

Of those writers who reject the advisory/investigative dichotomy, only Cartwright seems to have provided an analytical framework within which this intuitively appealing bifurcation of inquiries can be challenged. ${ }^{44}$ Cartwright suggests that the notion of an advisory commission (which, interestingly, he calls an investigation) is based on political and epistemological assumptions which are fundamentally different from those sustaining an investigatory commission (which he labels an inquiry). The concept of the advisory commission rests on the view that "truth is something which can best be discovered through diligent search. . . . The epitome of the . . . [advisory commission] is perhaps to be found in the scientific experiment ... the principle that truth is something obtainable through observation and measurement lies at the root of all ... [advisory commissions]".45 On the other hand, the concept of investigation is founded on the belief that "truth is something which is revealed in free and open debate between opposing interests. . . . The epitome of the ... [investigative commission] is the court of law . . the principle of truth winning out in free and open debate is central". "46 That is, to distinguish between advisory and investigative inquiries is not simply to identify towards which end of a two dimensional spectrum the focus of an inquiry's mandate should be placed; rather, this distinction implies two radically different and incompatible models of the inquiry function. Consequently, given Cartwright's critique, in order to evaluate

40. Wheare, Government by Committee (1955) discusses the origins of this distinction. See also Rhodes, supra n. 9 at 27; LeDain, supra n. 9 at 79; Cartwright, supra n. 9 at 224-226; L.R.C. Working Paper 17 passim. McRuer, supra n. 10 at 386, rejects outright this classification, as does Henderson, supra n. 10 at 507. But compare the remarks of Miller J. quoting Morrow J.A. in Re Orysiuk and the Queen (1977) 37 C.C.C. (2d) 445 at 455, as set out in Re Sedlmayr and the Commission into Royal American Shows (1978) 82 D.L.R. (3d) 161 at 173.

41. L.R.C. Working Paper 17 at 13.

42. Id.

43. LeDain, supra n. 9 at $79,85,86,91,92,95$.

44. Supra n. 9 at 224-226. See also McRuer, supra n. 10 at $463-466$.

45. Id.

46. Id. 
the usefulness of a division of inquiries into advisory and investigatory types, it is necessary to examine carefully the criteria and rationales advanced in support of the proposed distinction.

One of the clearest recent defences of the bifurcation of inquiries is that contained in Working Paper 17 of the Law Reform Commission of Canada. Yet when the Commission's recommendations are reviewed, it appears that no analytical test for distinguishing inquiries is offered; no criteria for identifying one or the other species are suggested, and it seems to be assumed that the advisory/investigatory distinction is obvious. Moreover, the Commission recommends leaving the choice as to whether an advisory or an investigatory inquiry should be appointed in any given circumstance entirely to the government which makes the appointment. It is difficult to believe that the distinction is either obvious or important if no basis for making the choice is provided and no means to review the decision to appoint one or the other of these two types is suggested.46a

If no analytical criteria for determining what is or what is not an investigatory or an advisory inquiry can be advanced, are there nevertheless certain functional considerations which may be identified? Here Working Paper 17 is more helpful. Starting from the premise that "form follows function" the Law Reform Commission suggests that because of the broad function of advisory inquiries their powers should be broadly tailored, and because of the narrow (and possibly dangerous) function of investigatory inquiries their form must be precise. ${ }^{47}$ In other words, it seems that the distinction is propounded simply to justify limiting the powers of certain inquiries, or structuring the procedures of others. In the Commission's view, the structure and powers of advisory inquiries "should promote the expression and transmittal to decisionmakers of relevant public opinion. Because of the nature of an advisory commission's work, subpoena and 'contempt' powers, and corresponding safeguards for witnesses, are unnecessary". ${ }^{48}$ On the other hand, the structure and powers of investigatory inquiries "must be strictly defined and carefully limited. There must be provision for the full powers necessary to discharge a mandate; but full and proper safeguards must be available for all those involved in the inquiry". ${ }^{49}$ However, when this functional distinction is viewed in the light of Cartwright's observations as to its epistemological foundations one sees that it assumes, at bottom, the same dichotomy which has plagued the field of judicial review of administrative action throughout this century-namely that between quasi-judicial and administrative functions: ${ }^{50}$ investigations (which, in the Commission's view, affect an individual's rights and should follow strict adjudicative procedural formalities) resemble the former; advisory inquiries (which, according to the Commission deal with matters of policy and may be inquisitorial in nature) resemble the latter. ${ }^{51}$ Given the extensive criticism of the classification of function process in administrative law literature, ${ }^{52}$ and the dissent on this point of one member

46a. Henderson, supra n. 10 at 507 , is particularly critical on this point.

47. L.R.C. Working Paper 17 at 41.

48. Id.

49. Id.

50. For a discussion of the problem and a recommendation that classification be abolished, see Crete, supra n. 10 at $647-661$.

51. L.R.C. Working Paper 17 at 23-42. See also Molot, supra n. 10 at 352.

52. See, e.g., Pepin et Ouellette, Principes de contentieux administratif (1979); Reid, Administrative Law and Practice (2nd ed. 1978). 
of the Law Reform Commission itself, ${ }^{53}$ one may conclude that even the functional rationale for bifurcating inquiries cannot withstand analysis.

It should be observed that the alternative to a legal division of inquiries into advisory and investigatory types for the purposes of delimiting their powers and procedures, is a shopping-list approach. Under such a scheme the appointing body would simply choose from a list of possible powers to grant the inquiry and then select the appropriate procedural safeguards from a second list. Although such an approach is consistent with the ad hoc nature of commissions, it is rejected by the Law Reform Commission for two reasons.53a First, it is feared that the Cabinet may make an unwise selection of inquiry attributes; secondly, under such a system no control over executive action could be asserted, and many unnecessary powers might be granted to an inquiry. Yet, even if the unworkable bifurcation suggested by the Commission were adopted, as long as the body to whom the inquiry is ultimately responsible retains control over the characterization of the inquiry type, there is no functional utility in attempting to distinguish the powers and procedures of investigatory vs. advisory commissions. Further, notwithstanding the recommendation that investigatory commissions be appointed only if the Cabinet deems a matter to be of "substantial public importance" $53 \mathrm{~b}$ since no outside review of this power to deem is contemplated, it is doubtful that unnecessary powers would not be granted. Thus, the taxonomy proposed by the Law Reform Commission shows itself to be difficult to apply in practice and hence, unworkable as an attempt to structure and limit the powers or procedures of commissions of inquiry.

If no functional catalogue of commission types can be developed for the purpose of deriving concrete legal implications from the salient political and administrative characteristics of inquiries, what approach should the law take to this phenomenon? In other words, from the perspective of judicial review of administrative action, what is the juridical nature of the ad hoc commission of inquiry? Traditionally, one finds this institution of government viewed in a similar light to all other statutory creations. In most analyses of inquiries by lawyers questions of powers and procedures are examined in the formal language of jurisdiction and natural justice; recommendations respecting the scope of judicial review seem to follow well-trodden paths; suggestions relating to remedies do not propose substantial departures from the system of extraordinary orders and writs which is applicable in the bureaucratic setting. ${ }^{54}$ Yet the above discussion of political and administrative features of inquiries has highlighted three characteristics of these commissions which serve to distinguish them from ordinary governmental institutions: they are ubiquitous and ad hoc; they are non-bureaucratic and highly flexible; they are publicly consultative. ${ }^{55}$ Moreover, from the legal perspective, because any bifurcation of inquiries into investigatory or advisory types (which merely reflects the quasi-judicial/administrative dichotomy) cannot be sustained, any attempt to characterize the function

53. See the comments of Mr. Justice Bouck, vice-chairman, Working Paper 17 at 89-91.

53a. L.R.C. Working Paper 17 at 25-26.

53b. Id. at 31 .

54. See Molot, supra n. 10 at 345-352; Crete, supra n. 10 at $670-675$; Henderson, supra n. 10 at 507 530.

55. The observations of Eisenberg, "Participation, Responsiveness and the Consultative Process" (1978) 92 Harv. L.R. 410, are instructive as to some of the consequences of these features. 
of inquiries, as this term is usually understood, for the purpose of identifying the possible grounds for judicial review of their powers and procedures, should be foresaken. Consequently, traditional assumptions and doctrines of administrative law should not be applied uncritically to this domain; rather, commissions should be viewed by administrative lawyers and judges solely on the basis of criteria which are coherent with their ad hoc, non-bureaucratic, publicly consultative nature. The implications of such a perspective will be traced out in Part IV of this paper.

\section{COMMISSIONS OF INQUIRY AND JUDICIAL REVIEW}

As noted earlier, the past few years have witnessed an explosion in governmental recourse to commissions of inquiry; concurrently, there has been a great increase in the number of judicial review applications touching on some aspect of an inquiry. Further, a large body of legal literature has appeared recently on judicial review of commissions. Nevertheless, in both cases and commentary one finds opinions which fundamentally are not compatible with the theory sustaining inquiries as an institution of government. In this Part, this incompatibility will be analysed through a discussion of three judicial review cases involving inquiries: $R e$ Copeland and McDonald et al., ${ }^{56} \mathrm{Re} B$ and Commission of Inquiry Re Department of Manpower and Immigration et al., ${ }^{57}$ and Landreville v. The Queen (No. 2).58 These involved, respectively, the following issues: a claim for disqualification on the grounds of bias, an application to prevent the continuation of an inquiry which allegedly was exceeding its jurisdiction, and an action for a declaration that the processes followed by a commission were ultra vires. Each of these issues is, of course, an archetype of judicial review of administrative action, and each directly raises the question of what practical legal consequences should flow from the nature, rationale and function of commissions of inquiry elaborated in Part II.

\section{A. The McDonald Commission}

The first case, Re Copeland and McDonald, is one of the most recent reported judgments on inquiries. Pursuant to Order-in-Council PC 19771911 , a Commission under the Great Seal of Canada was issued to $\mathbf{M r}$. Justice David C. McDonald, Mr. Donald S. Rickerd and Mr. Guy Gilbert to be commissioners under Part I of the Inquiries Act and to inquire into certain activities of the Royal Canadian Mounted Police. ${ }^{59}$ Under that commission their functions were outlined to be:

(a) to conduct such investigations as in the opinion of the Commissioners are necessary to determine the extent and prevalance of investigative practices or other activities involving members of the R.C.M.P. that are not authorized or provided for by law and, in this regard, to inquire into the relevant policies and procedures that govern the activities of the R.C.M.P. in the discharge of its responsibility to protect the security of Canada;

(b) to report the facts relating to any investigative action or other activity involving persons who were members of the R.C.M.P. that

56. Supra n. 5

57. (1975) 60 D.L.R. (3d) 339.

58. (1977) 75 D.L.R. (3d) 380.

59. Supra n. 56 at 730 . 
was not authorized or provided for by law as may be established before the Commission, and to advise as to any further action that the Commissioners may deem necessary and desirable in the public interest; and

(c) to advise and make such report as the Commissioners deem necessary and desirable in the interest of Canada, regarding the policies and procedures governing the activities of the R.C.M.P. in the discharge of its responsibility to protect the security of Canada, the means to implement such policies and procedures, as well as the adequacy of the laws of Canada, as they apply to such policies and procedures, having regard to the needs of the security of Canada.

Shortly after the appointment of the commissioners, an application for judicial review on the inquiry was brought by Paul D. Copeland before Mr. Justice Cattanach of the Federal Court, Trial Division. This application, pursuant to s. 18(a) of the Federal Court Act, ${ }^{60}$ was for a writ: 61

... prohibiting the respondents, as members of a Commission of Inquiry for the purpose of inquiring into certain activities of the Royal Canadian Mounted Police, from continuing their inquiry on the grounds of bias, in the legal sense, of each commissioner.

In particular, it was alleged that each commissioner was a political partisan of the Liberal Party of Canada, the Party which then formed the government and which was responsible for naming all three commissioners. Moreover, the application alleged that Mr. Justice McDonald had accompanied the then Prime Minister on a trip to the Orient, subsequent to his appointment as a commissioner. Further, it was alleged that $\mathrm{Mr}$. Gilbert and Mr. Rickerd had close business and personal relationships with members of the federal cabinet, especially with the then Solicitor-General who was responsible for the R.C.M.P. Other allegations supporting the claim of bias included the fact that (i) the Commission had expressed the view that certain alleged illegal activities of the R.C.M.P. may have been justified by the interests of national security and that (ii) since it is a function of the Commission to determine if any members of the Cabinet, or the Liberal Party, were cognizant of or complicit in such illegal activities, no active partisans of that Party should be commissioners. ${ }^{62}$

In giving judgment on this application for judicial review, Cattanach $J$. was required first to analyze the law respecting bias in administrative and other statutory bodies. After examining the decision of the Supreme Court of Canada in Committee for Justice and Liberty et al. v. National Energy Board, 63 he concluded that the expressions "reasonable apprehension of bias" and "real likelihood of bias" were essentially identical and that they established the test to be applied. However, Cattanach J. then went on to state that in order for bias towards an issue to exist there must be some issue to be determined by the Commission. He continued: ${ }^{64}$

60. R.S.C. 1970, (2nd Supp.) c. 10.

61. Supra n. 56 at 724 .

62. These facts are summarized from the judgment supra n. 56 at 727.

63. (1976) 68 D.L.R. (3d) 716.

64. Supra n. 56 at 729. 
For there to be an issue to be determined there must be a lis inter partes, that is to say a dispute between parties to be decided by the commission.

... if there is a lis inter partes the function is judicial in the case of courts of law and equally so in the case of a tribunal where issue between parties is decided where the function is more properly described as quasi-judicial.

Conversely, if there is no issue or lis to be determined, then the function of the tribunal is described as administrative and the principles of natural justice, particularly the common law concept of bias, do not apply with the same full force and effect to such tribunal as they apply to a quasi-judicial tribunal which is required to determine a quasi-lis.

For the purpose of determining whether a claim of bias could be raised, the court found it necessary to characterize the powers and functions of the Commission of Inquiry; that is, to determine if it was acting "judicially" or "purely administratively". After examining the order-incouncil constituting the commission, Mr. Justice Cattanach concluded: 65

The key words in the functions of the Commission are to "investigate", "inquire", "report the facts" and "to advise" with respect thereto.

Thus at its very highest the Commission is but a fact-finding, reporting and advisory body.

Counsel for Mr. Copeland cited the decision of the Supreme Court of Canada in Saulnier v. Quebec Police Commission ${ }^{66}$ in support of his assertion that even where inquiry functions are merely investigatory or recommendatory the rules of natural justice would apply. However, the court distinguished Saulnier on the basis that the recommendation of the Police Commission in that case directly affected Mr. Saulnier (i.e. he was the target of the inquiry), whereas the recommendations of the McDonald Commission would only indirectly affect $\mathrm{Mr}$. Copeland (i.e. the inquiry was into the conduct of a third party, the R.C.M.P.). Cattanach J. suggested: 67

No prejudice to any personal right or interest of his is foreseeable. . . . At most Mr.

Copeland may, and perhaps will be a witness at some stage of the inquiry. . . .

As a consequence, the court held that the inquiry was not a quasi-judicial function, and hence Mr. Copeland had no right to invoke the rules of natural justice. ${ }^{68}$

It was also alleged that the recently developed doctrine of procedural fairness could serve as means for raising the claim of bias. ${ }^{69} \mathrm{Mr}$. Justice Cattanach responded to this argument with the curt rejoinder: ${ }^{70}$

65. Id. at 730-731.

66. (1975) 57 D.L.R. (3d) 545.

67. Supra n. 56 at 735 . It is peculiar that the court would be concerned with the effect of the inquiry on Mr. Copeland. One wonders whether the court would have classified the Commission as quasi-judicial, had a member of the R.C.M.P. brought the application. The quoted passage seems to have more affinity with the question of standing than with the problem of determining an inquiry's function.

68. Crete, supra n. 10, feels that judgments such as Copeland reflect what he terms the binary approach to classification (i.e. the investigation is a pre-decisional step in a two-step decisional step) under which inquiries are usually not found to be quasi.judicial, while the Saulnier case is representative of the global approach (i.e. the investigation is an integral part of the decisional process) under which inquiries are habitually characterized as a quasi. judicial function. This point will be developed in greater detail infra, Part IV.

69. Cases such as Re Pergamon Press [1970] 3 W.L.R. 792 and Maxwell v. Dep't of Trade and Commerce (Times Newspaper Law Reports, June 25, 1974) were cited in support of this proposition.

70. Supra n. 56 at 731. In fairness to the court it should be pointed out that the Copeland case was decided on August 4,1978, prior to the Supreme Court of Canada decision in Nicholson v. Haldimand-Norfolk Board of Regional Commissioners of Police (1978) 88 D.L.R. (3d) 671, which recognized the existence of a duty of procedural fairness regardless of the function performed. 
But if a person is aggrieved by a decision that is required to be made on the basis of it being fair to the best ability of those who decide, then the remedy is political, not judicial.

That being so, it applies with much greater force to a tribunal which makes no decision.

Having decided that the function performed by the Commission was not quasi-judicial (from which conclusion it follows that breach of the rules of natural justice could not be invoked) and that the doctrine of procedural fairness did not open up a judicial remedy to Mr. Copeland, Cattanach J. then concluded that even should bias in the Commission be found to exist, for the purposes of judicial review, such bias would be irrelevant.

This decision raises several important questions about the role of inquiries in the Canadian legal system.70a Of particular note is the fact that the judgment does not seem to be consistent with one of the traditional rationales advanced for the existence of public inquiriesthat of providing for an objective, impartial investigatory/advisory governmental institution. How does this incongruity arise?

At the root of the reasons why Mr. Justice Cattanach felt the possible existence of bias to be irrelevant was his characterization of the inquiry process as non-judicial. This analysis apparently was reached because the Commission possessed no power to render a final decision. The court observed:71

The Commission reports to the Governor-in-Council and it is for him to decide what shall be done. He may implement the advice given in the report in whole or in part or he may consign the report to oblivion. The action to be taken thereon is exclusively his decision.

That is, the fact that no final determination is made supports the traditional view that inquiries are supplemental to other decision-making branches of government-the locus of decisional power remains unaffected by the existence of an inquiry.

Yet this very feature is crucial to understanding why objectivity and impartiality in commissions of inquiry must be rigorously guaranteed. As Cattanach $\mathrm{J}$. notes, the public inquiry is essentially a discretionary institution: the Governor-in-Council chooses whether or not to appoint it; he establishes its terms of reference; he selects its personnel; he disposes of its findings and recommendations. Thus, the power to make these ultimate choices lies completely in the hands of those to whom adherents of the traditional view of inquiries initially would deny such power. That is, the need for inquiries to perform a supplemental role to other governmental institutions often is justified because the executive is said to be unable to impartially or objectively investigate itself. However, by leaving the executive in complete control of the existence, scope, personnel and implementation of the recommendations of an inquiry, much of the justification for this supplemental role disappears. Only if the conduct of the inquiry process is itself beyond reproach does this rationale for commissions make sense.

Hence, if an inquiry is to have meaning for any of its participantsthose who appear directly as witnesses or parties seeking to have their version of the facts prevail, or those who are indirectly involved as members of the public being educated and/or convinced by the 
proceedings-its impartiality and procedural propriety must be assumed. In other words, the operation of the inquiry as a public institution of government presupposes the possibility that evidence given may influence the result and might be translated into action. At the present time the individual has no guarantees of such impartiality. In some cases, notably $R e$ The Ontario Crime Commission, ex parte Feeley and McDermott ${ }^{72}$ and Re Public Inquiries Act and Shulman, ${ }^{73}$ courts have relied upon statutory provisions defining the rights of "persons affected" in order to afford basic hearing rights to certain individuals. Moreover, in Saulnier v. Quebec Police Commission et al.,$^{74}$ the Supreme Court inferred a duty to act judicially from the fact that a statutory provision contained the right to be heard and the fact that the report of the Commission would have important effects on the rights of individuals. But in no previous reported decision has the issue of bias in a commission of inquiry been put squarely to the court and answered affirmatively. ${ }^{75}$ Not only have courts never held, when confronted with applications for review of inquiries on the grounds of bias, that the nemo judex rule applies, but also the liberalization suggested in certain cases with respect to audi alteram partem, ${ }^{76}$ not to mention the nascent doctrine of fairness, ${ }^{77}$ has not had an impact on bias proceedings. ${ }^{78}$ To this extent, at least one of the traditional justifications for inquiries-objectivity and impartiality in a public process-seems inconsistent with current judicial review doctrine.

\section{B. A Departmental Investigation}

A second case of relatively recent vintage which bears on the issue of the exact nature of an inquiry concerned an application for prohibition brought with respect to a Departmental Investigation. By order-in-council dated October 30, 1973, Madam Justice L'Heureux-Dubé was appointed under Part II of the federal Inquiries Act:

... to investigate and report upon the state and management of that part of the business of the Department of Manpower and Immigration (hereinafter referred to as "the Department") pertaining to

(a) the subject matter of, matters related to and the processing of the following Montreal files of the Department, namely: [over 100 files are listed]. . . .

72. (1962) 34 D.L.R. (2d) 451.

73. (1967) 63 D.L.R. (2d) 578.

74. Supra n. 66.

75. In Re Law and M.N.R. [1966] 2 O.R. 455 the court did hold, however, that bias was irrelevant to tax investigations. On the other hand, in Re Gooliah and Minister of Citizenship and Immigration (1967) 63 D.L.R. (2d) 224, the Manitoba Court of Appeal held that actual bias was a ground for reviewing an inquiry conducted by a Special Inquiry Officer under the Immigration Act. Since the court granted certiorari in this case, however, it is apparent that it had characterized the inquiry function as judicial or quasi-judicial. Moreover, D. P. Jones has argued that bias can be invoked against non-judicial functions. See (1977) 55 Can. Bar Rev. 718; (1977) 23 McGill L.J. 459; (1977) 23 McGill L.J. 605. Finally, it should be noted that review on grounds such as irrelevant considerations or improper purposes may be analogous to review for bias in non-judicial circumstances. See de Smith, Judicial Review of Administrative Action (3rd ed. 1973) at 67; Wade, Administrative Law (4th ed. 1978) at 405.

76. In addition to Saulnier, see Re Lingley and Hickman (1972) 33 D.L.R. (3d) 593; Chisholm v. Jamieson et al. [1974] 6 W.W.R. 169; Cotroni v. Quebec Police Commission (1977) 80 D.L.R. (3d) 490; Keable v. A.G. Canada et al. (1978) 90 D.L.R. (3d) 161; Royal American Shows Inc. v. Laycraft (1978) 82 D.L.R. (3d) 161.

77. In addition to the Nicholson case, supra n. 70, see Inuit Tapirisat v. Gov.-in-Council (1978) 24 N.R. 361 .

78. There is, of course, the possibility that this judicial reticence reflects the principle that the rule against bias may be expressly excluded (in these cases by the constitutive order-in-council), although the judgments do not suggest that this line of reasoning is being applied. 
(d) the conduct of any person who is or was in the service of the Department so far as that conduct relates to his official duties in respect of any of the matters referred to in paragraphs (a), (b), (c) or (e); and

(e) any matters incidental or relating to any of the matters referred to in paragraphs (a) to (d). ${ }^{79}$

Following the Commission hearings, but prior to the release of its recommendations, $\mathrm{Mr}$. $\mathrm{B}$. brought an application for $: 80$

1. a declaratory order to the effect that the respondents [the Commissioners] ... had no jurisdiction to make any report alleging misconduct against him; and

2. a writ of prohibition or order of prohibition against the respondents ... [the Commissioners] ... to enjoin them to desist from any further proceedings which might lead to the bringing of any such charge of misconduct.

Mr. Justice Addy's judgment with respect to this application is, at times, confusing. ${ }^{81}$ Because relief in the nature of prohibition was sought, again the court found it necessary to characterize the function of the commission. After a lengthy review of characterization cases the judgment proceeded to an analysis of the decision in Saulnier v. Quebec Police Commission et al. ${ }^{82}$ The court noted that in Saulnier, the Commission was held to be acting quasi-judicially: ${ }^{83}$

... because it was charged with making an investigation report which "may have important effects on the rights of persons dealt with in it" and because it was one which "impaired" the rights of the appellant.

But Addy J. refused to equate the existence of a right to be heard with the notion of a quasi-judicial function. ${ }^{84}$ Relying on Grauer et al. v. The Queen, ${ }^{85}$ he stated: ${ }^{86}$

I find no difficulty in coming to the conclusion that in the case at Bar, since no right is being in any way determined and since the duties and functions of the Commission are merely to report, it is not exercising a judicial or quasi-judicial function and, therefore, prohibition will not lie against the Commission, notwithstanding the fact that the right of the applicant to his reputation might well be seriously affected by the report and notwithstanding the fact that Part II of the Inquiries Act includes a statutory right to be heard. The sole duty under Part II is to "investigate and report" (refer to s. 6).

As a result, Mr. B. was deprived of the remedy of prohibition, of the applicability of the rules of natural justice and of all other incidents of characterization of a function as judicial or quasi-judicial. ${ }^{87}$

Moreover, the court also dismissed the applicant's claim for declaratory relief. Mr. Justice Addy concluded:88

Apart from special statutory provisions, a board, commission or tribunal, which is not performing a judicial or quasi-judicial function, is not liable to direct control by the

79. Supra n. 54 at 341.

80. Id. at 342 .

81. See the general observations in Mullan, The Federal Court Act (1978) at $42 \mathrm{ff}$.

82. Supra n. 66.

83. Supra n. 57 at 347.

84. This seems to be the position adopted by Pigeon J. in the later case Re Martineau and Butters and Matsqui Institution Inmate Disciplinary Board [1978] 1 S.C.R. 118.

85. [1973] F.C. 355.

86. Supra n. 57 at 349.

87. For a discussion of some of these in an inquiry context, see Crete, supra n. 10 at 661-670.

88. Supra n. 57 at 349 . 
courts in any way; . . . it is not subject to any of the above-mentioned equitable processes because it is not liable to be sued as a party and is therefore not itself amenable before the courts.

While suggesting that this unreviewability might potentially be overcome by constituting the Attorney-General as the party-defendant under $\mathbf{s}$. 18(b) of the Federal Court Act, Addy J. refused to permit Mr. B. to amend the style of cause or the proceedings so as to permit the application for judicial review on the merits to proceed. ${ }^{89}$ In any event, it is not clear whether review by way of declaration can be sought only for jurisdictional errors or whether this remedy also would lie for errors of law and mistakes about facts within jurisdiction; $; 0$ moreover, it is obvious that such control would not be as extensive as that exercisable on appeal by way of stated case.91

When carefully analyzed, this judgment also reflects some inconsistency with the theoretical role usually ascribed to the commission of inquiry. Generally it is acknowledged that because inquiries do not possess the attributes of any of the traditional branches of government, they lack some of the procedural and substantive safeguards associated with these usual government institutions; consequently, it is argued they should be subject to review on widely drawn grounds, and the court should abandon the strict and limited view of its supervisory jurisdiction heretobefore taken.92

What seems to underlie the deference of Addy J. is a view that the powers of the court should be reserved for the more usual manifestations of administrative power which result in non-investigatory or nonrecommendatory decisions. In effect, because prerogative remedies such as certiorari and prohibition developed in relation to inferior courts and tribunals (i.e. were tied to a classical conception of the judicial function), and because equitable relief by way of declaration was akin to the interpretation of written instruments (i.e. derived from the exercise of legislative power), judicial review of executive institutions such as boards and tribunals was coloured by these traditional classifications. Yet it is precisely the non-assimilability of the inquiry into traditional concepts of government which is the principal reason for asserting the need for external review.

The existence and effectiveness of the limited external controls on various aspects of day-to-day administrative government (controls which are summarized in concepts such as judicial independence, parliamentary supremacy, the rule of law, and judicial review of administrative action) presuppose an integrated political and bureaucratic fabric of internal control (i.e. ministerial responsibility and managerial hierarchies). Because the ad hoc inquiry lies outside this fabric and is theoretically guaranteed a freedom from political interference, non-political and nonbureaucratic control assumes a more significant role and should be enhanced. Two points should be noted: the necessity of challenging commissions of inquiry by suing the Attorney-General undermines their political independence; and a general exemption from review on other than formal jurisdictional grounds compromises the unique integrity of

89. Id. at 349-356.

90. On this issue see Mullan, "The Declaratory Judgment; Its Place as an Administrative Law Remedy in Nova Scotia" (1975), 2 Dal. L.J. 91.

91. Compare the provisions of the Public Inquiries Act, S.O. 1971, vol. 2, c. 49, s. 6.

92. See particularly Henderson, supra n. 10. 
inquiries; that is, inappropriate political or bureaucratic pressures and influences may not be subject to external redress. Consequently, in order for an inquiry to be a worthwhile exercise for those who participate in, and are subject to, its procedures, its scope and mandate must be subject to non-political control which is not limited by traditional views of administrative bureaucracies. The failure of courts to assert a wideranging review jurisdiction, but rather to restrict supervision to the circumstances envisioned by ordinary judicial remedies thus runs counter to the conclusions one would draw from another of the standard justifications for the inquiry-its distinction from other, ordinary branches of government and its uniqueness as a non-bureaucratic institution.

\section{Judicial Misconduct}

The third contemporary judicial review case which raises questions about the rationale for and role of public inquiries is Landreville v. The Queen (No. 2). ${ }^{93}$ By letters patent issued March 2, 1966, Mr. Justice Rand, a retired justice of the Supreme Court of Canada, was appointed a Commissioner under Part I of the Inquiries Act: ${ }^{94}$

(a) to inquire into the dealings of the Honourable Mr. Justice Landreville with Northern Ontario Natural Gas Limited or any of its officers, employees or representatives, or in the shares of the said company; and

(b) to advise whether, in the opinion of the Commissioner,

(i) anything done by Mr. Justice Landreville in the course of such dealings constituted misbehaviour in his official capacity as a judge of the Supreme Court of Ontario, or

(ii) whether the Honourable Mr. Justice Landreville has by such dealings proved himself unfit for the proper exercise of his judicial duties.

After eleven days of hearings a Report was issued on August 11, 1966, and made public on August 29, 1966. This Report contained a finding that Mr. Justice Landreville was in gross contempt of other tribunals; this finding ultimately led to his resignation as a judge, effective June 30 , 1967.

On August 4, 1972, Mr. Landreville brought an action against the Crown in which he sought a declaratory order that the Commissioner was invalidly appointed and that its Report was ultra vires. Moreover, he sought a writ of certiorari to have the records of the Commission removed to the court and to have the Report quashed.95 Upon an interlocutory motion to strike this statement of claim brought by the defendant on November 23, 1973, Mr. Justice Pratte of the Federal Court, Trial Division, ruled that the writ of certiorari would not lie, but that the action could proceed for a declaration in the circumstances alleged in the statement of claim. ${ }^{96}$ When the action for a declaration came to trial

93. Supra n. 58.

94. This paraphrase of the terms of reference is taken from supra n. 58 at 381 .

95. Mr. Landreville sought specifically the following relief: (a) A Declaration that the appointment of the said Commissioner was not authorized by the Inquiries Act and that consequently the said Report is null and void; (b) A Declaration that, if the said Commissioner was validly appointed to hold an Inquiry and make a Report, which the plaintiff denies, the said Report made by the Commissioner on August 11, 1966, should be removed into this court to be quashed by reason of the matters set out in paragraph 7 of this Declaration; (c) That a Writ of Certiorari be issued removing into this court the said Report and all records, proceedings, papers and transcripts of evidence relating to the said Inquiry and quash the said Report. See id. at 382.

96. Landreville v. The Queen (1973) 41 D.L.R. (3d) 574. Certiorari was refused in part because the inquiry was deemed not to be performing a quasi-judicial function. 
before Collier J., also of the Federal Court, Trial Division, three distinct submissions relating to the jurisdiction of the Commission and its powers were advanced. Of these, the court accepted only the third, namely that:97

... assuming the legality of the Commission, the Commissioner did not comply with the requirements of $\mathbf{s .} 13$ of the Inquiries Act.

\section{Section 13 of the federal Inquiries Act states:98}

No report shall be made against any person until reasonable notice has been given to him of the charge of misconduct alleged against him and he has been allowed full opportunity to be heard in person or by counsel.

Mr. Justice Collier found as a fact that the Commission was not reconvened after its Report was drawn up. Normally, when an individual is the subject of an inquiry, the requirements of section 13 are met if that individual is present and represented by counsel throughout the inquiry process. However, in this case the court found that the particular charge of misconduct contained in the Report (i.e. gross contempt of other tribunals) was not included, by implication or necessary intendment, in the Commission's terms of reference.$^{99}$ In other words, since Landreville was only given an opportunity, during the inquiry, to respond to charges respecting Northern Ontario Natural Gas, and was not even aware that a finding of contempt might be made against him, the failure to reconvene the Commission prior to the release of its Report constituted a denial of Mr. Landreville's right to respond under section $13 .{ }^{100}$ Hence the court issued a declaration that the Commissioner did not follow the provisions of the Inquiries Act and consequently his Report was ultra vires.

Again this decision raises an important question with respect to the nature of public inquiries. For throughout justificatory discussions of inquiries it is assumed that, in the main, they perform two tasks which cannot be accomplished as effectively by other branches of government: investigating and advising. Inquiries are necessary because courts make final decisions on questions of pre-existing law and fact, whereas there is usually no such law for an inquiry to apply; they are also necessary because their flexible procedure permits the inappropriate features of both a rigorous inquisitorial process and a strict adversarial adjudicative framework to be avoided. Yet the interpretation given to section 13 by Collier J. seems to suggest that inquiries are merely surrogate criminal trials. ${ }^{101}$

At bottom, this transformation in the nature of the inquiry probably occurred because of how the court characterized the Royal Commission. Collier J. stated: 102

This was a somewhat unusual Royal Commission. The majority of Royal Commissions seem to be constituted to investigate a particular subject, thing or state of affairs. Rarely do they relate to one person. This Commission was, however, directed to the investigation of one particular person and his dealings with a certain company, its officers, or its shares. The Commissioner was requested to inquire into those dealings

97. Supra n. 58 at 383.

98. R.S.C. 1970 , c. I-13.

99. Supra n. 58 at $403-404$.

100. On the facts of Landreville this conclusion may be arguable. Expressions such as "anything done ... in course of dealings. ..." are capable of application to testimony in trials investigating such dealings without straining their meaning. Nevertheless, this point is tangential to the principal argument here presented.

101. For a commentary praising such an approach, see Henderson, supra n. 10 at 497 and 502-530.

102. Supra n. 58 at 404. 
and to express an opinion whether in the course of them, there had been misbehaviour by the plaintiff as a judge, or whether the plaintiff, by the dealings had proved himself unfit. I am unable to see how those general terms indicated to the plaintiff there would, or might be, an allegation of gross contempt of certain tribunals amounting to misconduct.

Later in the judgment this criminal law characterization was carried even further. After referring to the decision in Re Crabbe and Jamieson, ${ }^{103} \mathrm{Mr}$. Justice Collier concluded:104

The substance of the proposed allegations of misconduct set out in conclusion II and III [of the Commission Report] should have been made known to the plaintiff in accordance with 8.13 . The plaintiff should then have been given the opportunity to meet those specific charges.

It is instructive that reference was made to the Crabbe case since under the provisions of the Canada Shipping Act, ${ }^{105}$ the investigatory panel is constituted as a court with its proceedings assimilated as far as possible to those of ordinary courts, and is given the power to make final determinations respecting suspension or cancellation of a licence certificate. Although referred to as investigations, these procedures under the Canada Shipping Act in fact are those of an inquisitorial adjudication which in no way are analogous to those of a commission of inquiry.

If an inquiry is to be able to competently perform its supplementary investigative/advisory function (which by admission cannot be performed well by courts), it seems curious that an attempt is made to turn the Commission into a quasi-criminal trial. Where the person whose conduct is the subject of an adverse finding is the same person about whom the inquiry is conducted, it is questionable whether section 13 does in fact provide a right to rebut the inquiry findings. ${ }^{106}$ Rather, the section seems designed to protect those who were witnesses, as in $\operatorname{Re} B$, those who may be implicated although not a witness, as in Re Copeland, or those who make allegations, as in Re Shulman. In other words, section 13 appears to be the logical concomitant of the fact that the inquiry is nonadversarial. Hence, the decision in Landreville seems to run counter to another important justification offered for the existence of inquiries-that of being a flexible and adaptable body which is eminently suited to performing tasks that other institutions of government are less well able to accomplish.

\section{Conclusions}

These brief comments on recent judicial review decisions concerned with commissions of inquiry raise several important issues in administrative law. Three points should be highlighted. In the first place, the cases do not seem to be coherent with justifications traditionally offered for inquiries: often the values protected on review are antithetical to those which commissions are thought to reflect (Re Landreville); sometimes the court fails to protect a value which is essential to the functioning of commissions in the manner that underlying theory would suggest (Re Copeland). Secondly, these decisions do not seem to reflect an

103. (1972) 29 D.L.R. (3d) 716.

104. Supra n. 58 at 405.

105. R.S.C. 1970 , c. S-9, $88.548,556,568$.

106. There are no cases other than Landreville on this point. The Law Reform Commission is not clear on their interpretation of section 13 (at 50-51), although their recommendations for a new Act clearly would contemplate notice even to an individual who was the subject of an inquiry. 
appreciation of the nature and role of inquiries in Canadian government: it is not unusual for commissions to be seen by the courts simply as another manifestation of government delegation, and hence, no different than ordinary "investigatory or recommendatory" functions $(R e B)$. Finally, the judgments proceed on the basis of the traditional classificatory concerns of administrative law: no review for bias, or no review by way of prohibition or certiorari for non-judicial functions (Re Copeland, $\operatorname{Re} B$, Landreville); strict adherence to the adjudicative model if rights affected (Landreville); no procedural rights if no conclusive decision (Re Copeland); no judgment on the merits in judicial review proceedings $(\operatorname{Re} B)$. Each of these reflects an important difficulty in the current approach to judicial review of ad hoc inquiries; each compels a reexamination and re-integration of the theory of commissions of inquiry into the practice of administrative law.

\section{A THEORY OF JUDICIAL REVIEW OF $A D H O C$ COMMISSIONS OF INQUIRY}

The current framework of judicial review of inquiries has been almost universally condemned. ${ }^{107}$ The necessity of classification of function, the poverty of remedies and the limited grounds for review (given the substantial powers of commissions) have been particularly subject to criticism. Representative of these views are the following comments by Henderson: ${ }^{108}$

.. . Royal Commissions established by government should not be granted coercive jurisdiction, their mandate should be narrow and precise, and general principles of procedure should be provided. A Royal Commission with coercive jurisdiction should only be established by resolution, at the minimum, of the House of Commons. . . . The legislation governing such commission [sic] should provide for safeguards. These safeguards should include the following: (a) the coercive power should only be exercised through the courts, not directly by the commission; (b) precise and definite procedures should be established; (c) the rules of evidence should generally apply; (d) the immunities and privileges of witnesses and persons under investigation should be respected; (e) the action, decisions and orders of the commissions should yield to ordinary methods of judicial review; (f) the report and recommendations of commissions should have no status in any other proceeding.

These recommendations and observations reflect three underlying themes: increased judicialization of commissions; assimilation of inquiries to other, bureaucratic, administrative bodies; slightly wider, but not radically different, procedures for judicial review. There can be no doubt that these recommendations and the themes they represent will make certain aspects of inquiries more palatable to lawyers. It is also the case that they will likely lead to a correction of the most obvious legal abuses of commissions..$^{109} \mathrm{But}$, in the final analysis, they may undermine the utility of the inquiry as a governmental institution: for these recommendations are fundamentally inconsistent with the theory of

107. See especially Henderson, "Abuse of Powers by Royal Commissions" [1979] Special Lectures of L.S.U.C. 493; Crête, "L'enquête publique et les critères de contrôle judiciaire exercés par les enquêteurs" (1978) 19 C. de D. 643; Molot, "Administrative Discretion and Current Judicial Activism" (1979) 11 Ott. L.R. 337; and "Rapport du Comité d'étude du Québec sur les commissions d'enquête" (1976) $36 R$. du B. 545.

108. Henderson, id. at 530 .

109. The recommendations of the L.R.C. Working Paper 17 also are directed to these goals. See pages 43-63. 
commissions of inquiry examined in Part $I ; 110$ moreover, they do not at all address the kinds of problems which arose in $\operatorname{Re} C o p e l a n d, \operatorname{Re} B$, and Landreville. Consequently, if one is to develop an adequate theory of inquiries, a different approach to judicial review seems to be indicated.

How are the underlying rationales for inquiries, such as those set out by the Law Reform Commission of Canada, to be reconciled with liability to, procedures of, or grounds for judicial review? To answer this question competently, a thorough analysis of the relationship between the Commission of Inquiry and other processes of government must be undertaken. The supplemental role of inquiries (to the executive, legislative and judicial branches) is only one small part of this relationship. A much more important aspect is the suppressant effect which the inquiry exercises on the activity of these branches of government: court proceedings on contiguous matters are adjourned, and fresh judicial proceedings are pre-empted; investigation in Parliament by the legislative branch is curtailed and committee activity on the subject matter of the commission is suspended; the executive itself is relieved of responsibility for taking immediate action on any topic under inquiry. Thus, the inquiry serves to insulate government from the pressure to act. Moreover, since the decision-making body which is ultimately responsible for implementing commission findings or recommendations establishes the terms of inquiry and appoints its personnel, it is able effectively to sterilize conflict and avoid unwanted stimuli to activity by predetermining a commission's jurisdiction. Finally, the inquiry mechanism prevents contentious issues from being framed in a manner to which other government branches are able to respond; by keeping the information gathering (i.e. the premise developing) stage open, one suspends the decisional stage of any process.

But apart from its usurping effect on other governmental bodies, the inquiry also serves the important ancillary role of inducing the public to divert its attention from the primary decision-making segments of government to a body which has no power to effect change or take action. That is, the mere existence of the inquiry structures public response to the subject matter of the commission, deflecting it to a non-volatile medium; the shaping of and response to social input is entrusted to a nonadversarial, pacifying institution. In addition, the existence of an inquiry on a particular matter often is offered by affected parties as a reason for not pursuing other avenues of recourse: hypothetically, it could be suggested that for Mr. Landreville, the inquiry pre-empted his desire for a joint address of the Senate and House of Commons; for Mr. Copeland, the inquiry deflected his attention from an invasion of privacy suit or a private prosecution for wiretapping; for $\mathrm{Mr}$. B, the inquiry served to induce him not to file a grievance or take other action under his collective agreement. ${ }^{111}$ In view of the fact that inquiries themselves have no decisional power, this reluctance to pursue other recourses may seem

110. They do not take into account the unique, flexible and public nature of ad hoc commissions; they presuppose a unity between ad hoc inquiries and usual investigatory or recommendatory functions.

111. This is not only true if the inquiry is censorial in orientation. With respect to the Inquiry Into the Non-Medical Use of Drugs, one could say that lobbying in Parliament, electoral pressures, etc., were alternative measures not pursued. 
paradoxical.111a Yet almost universally, interested persons devote their sole attention to commission proceedings once an inquiry is appointed.

The above observations about the relationship of commissions of inquiry to other government processes, or their effect on individuals are not, however, intended to imply that there is anything necessarily conspiratorial about inquiries. It is not here asserted that inquiries are always designed to squelch criticism (i.e. that governments purposely use them to bury controversial issues in a forum where only ineffective criticism is possible); nor is it to claim that those who do not pursue other recourses such as lobbying, legislation or lawsuits consciously abdicate these possibilities (i.e. that purposely they do not want final decisions taken on the subject matter of the inquiry). Rather, the preceding paragraphs should be taken as suggesting that there are problems, issues and solutions which both the government (including, by implication, Parliament and the courts also) and the public (all those who might take other steps) are either unable or unwilling to articulate at a given moment: this inarticulateness finds expression in the appointment of a commission of inquiry. From this perspective, issues such as bias, or the characterization of inquiries and the scope of review, or whether an adversarial, inquisitorial or other procedural paradigm should be adopted, take on important new meaning. ${ }^{12}$

When it is claimed that the government invokes, and the public participates in an inquiry because of an inability to state the issue which the commission is structured to elucidate, one is not talking of an absolute inability. A commission of inquiry never embarks upon its mission with a tabula rasa; the social and/or political context of the day, as well as its very terms of reference, delimit the scope of the inquiry and direct its processes. To some degree, therefore, the issue or some issue must be capable of articulation before a commission is established; there can be no absolute inability to state an issue, only greater or lesser degrees of inability or unwillingness to formulate precise matters for consideration. Furthermore, it is not claimed that this unwillingness results from conscious dissimulation: sometimes the effort required to develop an issue at a given stage in the political process is simply too great; often it is inexpedient or impractical to do so; occasionally, there are so many competing interests that the problem seems insurmountably polycentricthat is, incapable of resolution on the basis of an either/or decision. ${ }^{113}$ What is clear, however, is that the very existence of an inquiry testifies to the existence of an event or a situation which is to some extent capable of identification and isolation.

Consequently, it is necessary to examine what it means to say that parties are unwilling to state the issue. This point can be clarified through an analysis of the way in which human beings interpret various events. It should be remembered that any given "fact situation" can be understood

111a. Of course, it may be that the parties are satisfied simply by the publicity accorded to their grievances. Yet if this were the case one would not expect 80 many applications for judicial review.

112. Briefly, the following points would become relevant: A public inquiry which is itself biased would be unable or unwilling to state the issue; it would also do so if review were confined only to jurisdictional matters; or finally, if its processes were transformed into an adversarial proceeding centering on clearly defined, precise points. See infra, passim.

113. On polycentricity see Fuller, "The Forms and Limits of Adjudication" (1979) 92 Harv. L.R. 353; Eisenberg, "Participation, Responsiveness and the Consultative Process" (1979) 92 Harv. L.R. 410. 
on many different levels: any conflict can be stated in a variety of ways. More importantly, how it is "broken down", "fractionated" or "perceived" often is fundamental to its resolution.114 For example, a judicial review application respecting a Human Rights Commission decision relating to a refusal to permit a young girl to play on a boys' hockey team may be viewed in several ways. ${ }^{115}$ The applicant may claim that the issue is human rights; the respondent, that the issue is sexual decency. Others may see the issue in terms of the availability of municipal ice-skating facilities, or the omnipresence of the "big-brother" state personified by Human Rights Commissions, or the deference of reviewing courts to administrative tribunals. Each of these perspectives legitimately can be advanced as the issue in dispute; yet each leads to a fundamentally different way of viewing the problem presented in the "fact situation", and influences the factors we may deem necessary to its resolution. Hence, each way of formulating the issue may produce a different result.

It is clear that many factors will bear on the process of issue development. Normally, however, in adversarial adjudication it is the parties themselves who are primarily responsible for fractionating conflict by stating and arguing issues. Through procedures such as pleadings and discovery various issues capable of third-party adjudication are shaped and presented by litigants. The above claim that participants are unwilling to state the issue to which the inquiry is addressed therefore means simply that they themselves do not wish to take the initiative in formulating the conflict in such a way that an adjudicative decision thereon can be made. All inquiries, whether primarily advisory or investigatory, perform this same role: they offer those who establish an inquiry, as well as those who participate in its processes, an opportunity to avoid responsibility for producing or stating an issue, while at the same time preventing other state agencies and branches of government from dealing with a particular area of concern. In other words, inquiries serve to preclude the definitive fractionation of conflict (either by a branch of government or by the public) at a time which the decisionmaking institution which ultimately has the power to act upon an issue so formulated or to make a conclusive determination thereupon, deems premature. ${ }^{116}$ As a result, the key question with respect to any commission of inquiry is whether or not it is beneficial or appropriate to avoid the production and stating of an issue at a certain institutional stage.

In many respects the question as to how, when, and by whom an issue is stated is fundamental to all legal activity. Even though many of the procedural attributes of various decisional processes are designed to facilitate issue-production, it is sometimes the case that such systems quite properly do not seek to accomplish this goal. In fact, it has been argued that much of the judicial function, the paradigm process for stating, sharpening and resolving conflict, involves avoiding decisions upon all of the issues tendered for adjudication through restrictive mechanisms such as standing, mootness or ripeness.117 This avoidance

114. See the observations in Fisher, "Fractionating Conflict" (1964) 93 Daedalus 920.

115. This very "fact situation" arose in Re Cummings and Ontario Minor Hockey Association (1978) 21 O.R. (2d) 389.

116. For an analysis which parallels the above, see Joseph Vining's examination of the law of standing, Legal Identity (1978) at 139-181.

117. See Bickel, The Least Dangerous Branch (1962) at 127.169; compare Gunther, "The Subtle Vices of the Passive Virtues" (1964) 64 Col. L.R. 1. 
facilitates the autonomy of other societal decision-makers (who are, in the adjudicative setting, usually the parties themselves) while at the same time fostering in them the development of a deeper insight into other aspects (that is, different perceptions) of the problem submitted for decision. In other words, the court might function:118

. . . not as a font of behavioural edicts, but as a partner in a dialogue, as an institution of state systematically engaged in helping the culture articulate and cope with the tensions that are set up as mankind seeks to work its way to ever-new adjustments in the liberation of its capacities.

From this perspective, it may be argued that if the judicial branch (where procedures and structures are designed to produce issues for decision) may legitimately avoid accepting issues as framed by litigants, then other governmental instrumentalities such as inquiries may also respond in this manner. In other words, it may be that, regardless of how the parties wish to see the mandate of the inquiry (i.e. as a device set up to define all the relevant issues, if not to propose solutions for them), the commission can justifiably refuse this mandate.

The conception of an inquiry as a "physician of issues" becomes even more persuasive when it is remembered how problems are usually presented to commissions. The relegation of a matter to an inquiry in a raw, undifferentiated form where conflict is only crudely perceived must be seen in many cases as an attempt to escape responsibility for deciding how the issues involved should be stated. Such relegation does not even compel the parties to struggle with various permutations of issue formulation (as in adversarial adjudication), since the inquiry has no power of conclusive decision; parties present a "problem situation" to an inquiry not for resolution, but rather to have the commission take on the role of determining what the issue or issues involved are. Thus, in the above instances, if the inquiry actually defines an issue and recommends a solution, it will neither facilitate the autonomy of other decision-makers (that is, it will permit them to avoid having personally to decide what to do), nor foster insight by participants into the problems presented (that is, like non-socratic teaching in law school, it will suppress creativity and sensitivity to alternative points of view). In such cases, the inquiry does not serve at all to supplement the decision processes of other institutions of government; rather, it undermines and perverts them. Responsible decision-making presupposes facts to be understood, standards to be developed, and judgment to be exercised. The inter-relatedness of each of these tasks requires no emphasis here. Yet unless an inquiry functions so as to keep these mutually dependent elements always in the mind of the decision-maker, a truncated perception of responsibility by that decisionmaker is inevitable. Hence, a corruption of the processes of legitimate governmental decision-making institutions (Parliament, the Cabinet, the courts, administrative agencies, etc.) is likely to result.

In light of these observations, one may conclude that the commission of inquiry will be a legitimate form of state institution only if its result is to compel its creators and participants to themselves accept responsibility for formulating and understanding the conflict submitted for investigation and advice. In other words, a commission of inquiry can only be successful in terms of its traditional justification when it does not define

118. Stone, "Existential Humanism and the Law" in Existential Humanistic Psychology (1971) at 173. 
the issue, nor itself become the issue in dispute. In particular, if the principal concern which arises vis-à-vis any problem submitted to an ad hoc inquiry is seen as (i) the personnel of the commission; (ii) the scope of its mandate; or (iii) the exercise of its powers, then the conflict has been formulated in terms of the inquiry itself. Other, potentially more meaningful, possibilities are suppressed and quickly disappear from view. Moreover, if the inquiry becomes the issue, it is no longer able to compel others to themselves assume responsibility for formulating issues.

Under such a conception, not only must an inquiry avoid becoming the issue during its processes, it must also avoid having its report and recommendations become the subject of conflict. While the report of an inquiry cannot, like the judgment of a court which refuses to decide the issue submitted by litigants, overtly decline to address the problem referred, it must not simply present one characterization of that problem. By offering alternative formulations of the issues presented, the report prevents those who must decide from relegating it to the nether world of political indifference; the report which refuses to state an issue and recommendations thereon will not itself become the central issue in any future debate on that subject. If inquiries are indeed established either to relieve decision-makers from the need to fractionate conflict, or to themselves become the issue, or both, then the truly significant inquiry refuses or avoids doing both. In doing so, it serves to mediate urgent necessity and reflection; to redefine what is beneficial or harmful in society; to confirm, yet also challenge constituted authority; to diffuse feelings of hurt and rage in individual cases; that is, just as courts are able (within the confines of adversarial adjudication), ad hoc inquiries may also (within the investigatory/advisory framework) conceive of themselves, and act as something like a cultural therapist.119 Le Dain expresses the essence of this idea in the following way: 120

What gives an inquiry of this kind its social function is that it becomes, whether it likes it or not, part of this ongoing social process. There is action and interaction.

If the underlying rationale and nature of commissions of inquiries presented in the preceding paragraphs is correct, then they can perform an important public function even though they reflect a desire to postpone decision or an unwillingness to formulate issues, or a repression of "unpleasant" problems. But rethinking inquiries in this way compels a reconsideration of the scope and manner of judicial review of commissions. In current theory the commission of inquiry is not subject to supervision and control by the judiciary except on limited grounds: the court will ensure the constitutionality of the mandate and activities of an inquiry; the court will control the vires of an inquiry to prevent it from exceeding or abusing its jurisdiction, and will not permit an inquiry to stray outside its terms of references; if the ancillary powers of a commission impair the liberty or property of a person, or if the inquiry report is susceptible of affecting the rights of a person, certain adjudicative-type procedural safeguards as to their exercise will be implied. ${ }^{121}$ However, a theory of review such as this, which focusses on jurisdiction and judicialization, does not contemplate any restraint on the

119. Id. at 169.

120. Supra n. 9 at 85.

121. For an outline of recent cases and an examination of the current scope of review, see, in particular, Molot, supra n. 10; Crete, supra n. 10; Henderson, supra n. 10. 
inquiry as an issue-avoidance mechanism; neither does it provide any grounds for ensuring that the commission does not consciously make itself the issue, nor does it serve to guarantee the conditions under which the participation of those seeking to avoid responsibility for formulating conflict can be therapeutically meaningful in the sense indicated earlier. A brief review of the three cases discussed in Part III will clarify what the scope of supervision under this new model of ad hoc commissions should be.

In $R e$ Copeland the potential existence of bias in inquiries was shown to be a crucial matter. First, if a commission is partial to its appointers it will also avoid fractionating the conflict in a way which compels the executive to act or to act against its interests. Secondly, if bias exists, those who forsake other institutions of government and invest time and resources in participation before an inquiry have no assurance that their input into the process of finding alternative ways of framing the issue will receive consideration; the action and interaction envisioned by LeDain is compromised. Finally, in adversarial adjudication one expects the judge to keep an open mind and not to decide a case until he has heard all the evidence; hence the need to censure bias. In the inquiry context commissioners must not only avoid formulating recommendations until they have fully examined a matter; they must also avoid deciding what the issue or issues for decision are until that time. Consequently, to perform this task effectively they must be free not only from bias as to the issue ultimately to be decided, but also from partiality as to what the issue is.122 This analysis reveals, therefore, that classification of function of an inquiry for the purpose of determining whether a claim for bias may lie misses the fundamental point. In ad hoc commissions, bias is always relevant.

In $\operatorname{Re} B$ the need for review on the merits and not just jurisdictional review as conceived by traditional remedies was also shown to be of vital importance. First, although jurisdictional review serves a prophylactic effect at the extremities of inquiry activity, it imposes no control over the discretionary content of commission proceedings. Aberrant orientations, as exemplified by wrong questions, improper purposes or irrelevant considerations, must be reviewable in order that inquiries do not become a witch-hunt or a free-for-all. While in some cases review has encompassed these wide-ranging considerations, generally the scope of supervision has been restricted to questions touching the pure theory of jurisdiction. Second, what often is most at stake in cases involving inquiries is the inquiry itself; hence, external review must extend to the existence of the inquiry itself. While it may not be advisable to grant the judiciary the power to review the decision to create inquiries (other than on jurisdictional grounds) it is arguable that courts should be permitted to evaluate when an inquiry has itself become the issue, and issue a declaration in such instances that the commission's mandate should be terminated. One notable circumstance where such a proceeding would be advantageous is Quebec's Commission of Inquiry Into Organized Crime, which seems to have developed a permanent existence and can no longer be characterized as ad hoc. Finally, the justification for the limited remedies of the common law, i.e. that they can serve the purpose of

122. For a more detailed treatment of this idea in an analogous field see Bickel, The Morality of Consent (1975). 
restricting review and preventing undue judicial interference with administrative bureaucracies, is not relevant to non-bureaucratic governmental institutions. Ordinary administrative structures do not usurp the processes of other branches of government; inquiries do. Consequently, the obverse of the judicial presumption against the capricious application of a law or exercise of a discretion, namely, the capricious suspension of the processes of the law, should be reviewable. ${ }^{123}$ Once again, the traditional approach to review is shown to be wanting, not because of problems of characterization, but because the remedies available fail to guarantee that inquiries, and those who are parties to them, do not subvert the commission function.

In Landreville, the importance of protecting the distinctive procedural integrity of the inquiry became clear. First, interpreting statutory hearing rights according to a paradigm of adjudication compels the inquiry to determine prematurely what are the issue or issues at stake, and to adopt an inquisitorial process. But given that the real question underlying an application for judicial review is often the existence of the inquiry, a reviewing court may be faced with assessing the propriety of a process which has no other goal than to exist. The medium may be the message. Since in theory, that process is designed to embody most of the things that a common law adversarial system is not (in terms of issue determination, normative context, factual certainty, responsiveness to proofs and arguments), it is nefarious to review the process by evaluating it against an adjudicative paradigm. Secondly, the preoccupation with procedural rights touching the concept audi alteram partem ignores not only the decisional process within the inquiry, but the decisional process which is contingent upon the inquiry report. Just as review should encompass the power to declare an inquiry's mandate terminated, it should also contemplate projection of that mandate into the future by compelling publication of a commission report. The usual approach of treating inquiries as the pre-decisional stage in a two-step process (which is consistent with the adjudicative model) means that their reports are viewed essentially as the private information of the decision-maker. Yet the model discussed shows the importance of continuing what LeDain terms the public dialogue through public release of an inquiry report. Finally, in arguing for more judicialized procedures lawyers are encouraging inquiries to become decisional bodies. Representation of parties, cross-examination, and strict application of the rules of evidence induce issue fractionation. This, in turn, leads to factual conclusions and the application of standards. Ultimately, recommendations casting opprobrium on parties result. All of this becomes legitimized not because of the function of inquiries (or the scope of their mandate), but because any person apt to be affected by inquiry proceedings, or such conclusions has already "had his day in court". Thus, by encouraging adversarial procedures, one also encourages inquiries to produce reports and recommendations which make such proceedings necessary; and this occurs notwithstanding the unsuitability of the inquiry process to undertaking such tasks. ${ }^{124}$ In this third circumstance, therefore, the

123. In many respects a parallel may be drawn between the use of the inquiry in this way and the attempted use of prerogative to suspend the operation of the law. See most recently, $R$. v. Catagas (1977) 33 C.C.C. (2d) 296.

124. A thorough jurisprudential treatment of this problem may be found in Fuller, "American Legal Philosophy at Mid-Century" (1954) $6 \mathrm{~J}$. of Leg. Ed. 457. 
standard review model is also deficient: continuing to view certain inquiries from the perspective of adjudication undermines their internal procedures and ignores the significance of projecting the process forward to the time that a report is released; it also prevents inquiries from serving the therapeutic role which they are ideally designed to perform by forcing them to decide issues which have been prematurely fractionated.

Although the judgments in $\operatorname{Re}$ Copeland and $R e B$ have been criticized by many on the same grounds as were advanced above, the basis of comment usually has reflected a desire for increased judicialization of commissions. This attitude is consistent with the decision in Landreville which has been almost universally praised. However, the analysis in Part III reveals that all three decisions are inconsistent with the traditional view of an inquiry's role. In other words, these judgments seem to reveal an inability to comprehend the political and administrative nature of the public inquiry. A second look at the rationale for inquiries resulted in the derivation of an alternative explanation of commissions. When applied to the problems raised in $R e$ Copeland, $R e B$ and Landreville, this analysis not only provided a legal justification for the solutions which seemed theoretically correct (in the light of traditional assessments of commissions) while at the same time intuitively sound (given the actual processes of inquiries), but also revealed why the often advocated proposal for increased judicialization of commissions of inquiry is inappropriate.

\section{CONCLUSION}

At the present time, the principal underlying theory of commissions of inquiry sees them as a supplement to the three traditional branches of government, performing ordinary investigatory and/or recommendatory functions. Yet it has been shown that inquiries also may serve a legitimate socio-psychological role, as an institutional cultural therapist; or they may assume an illegitimate socio-psychological role, as a device for the repressive tolerance of society's criticism. At the present time, there are no external guarantees that commissions will not take on the latter of these subsidiary roles: the limited review powers of courts (or any other body), where only questions of jurisdiction are addressed, do not extend to the merits of any process; the classification exercise (and the desire to judicialize) compels the very premature fractionation of conflict which inquiries were designed to avoid. Moreover, continuing this current approach to review neglects the most fundamental question of allwhether a given inquiry or our present conception of inquiries should exist.

In the case of commissions of inquiry, one is confronted by a process whose principal raison d'être is its process: there may be no goal for the process beyond the fact that it exists. Consequently, public or judicial criticism of the personnel, mandate or procedures of an inquiry fails to attack the preliminary problem of the existence of inquiries as supplemental to other government institutions. Not only do such criticisms obscure this basic question, they contribute to the perpetuation of the process itself. Directing social criticism at the procedures of a commission legitimizes the role of inquiries and serves to deflect attention from the abdication by its creators of their function of fractionating and resolving 
social and political conflict. When an inquiry itself becomes the issue, it, by this fact alone, has assumed its illegitimate role.

A genuine attempt to understand commissions of inquiry must begin with an examination of the legitimating functions they serve in our legal system. To date, this question has not been squarely addressed by the legislature, the executive, or most recently the Law Reform Commission of Canada. Moreover, given the reluctance by courts to consider this issue on review applications, meaningful reform of inquiries as an institution of government will not occur quickly. Finally, until judicial review itself becomes broader than jurisdictional in scope and other than judicialized in procedural orientation, the legitimate therapeutic function of ad hoc commissions of inquiries is unlikely to become predominant in the near future. ${ }^{125}$

125. A less pessimistic view is given by LeDain, supra $\mathrm{n}$. 9. For a brilliant endeavour to explain another facet of public law in these terms, as well as an interpretation of recent decisions in the United States which suggests that this reorientation is under way, see Vining, Legal Identity (1978). 